\title{
SIR WILLIAM ASHLEY: SOME UNPUBLISHED LETTERS*
}

William James Ashley was in his day (1860-1927) an international figure important both as a writer and educator in the field of economic history. Born in Bermondsey, the son of a journeyman hatter, he went up to Balliol on a scholarship in 1878 and won a first class in Modern History in 188r. The direction of his professional career was established in the years immediately following his degree-he attended Arnold Toynbee's famous Oxford lectures on the Industrial Revolution and became committed to economic history and social reform; and he made three short visits to Germany, met the leading members of the German Historical School, and embarked upon a full study of German economic literature. Economics, the historical approach, and social reform were to be his lifelong interests. From 1888 to 1892 he was Professor of Political Economy at the University of Toronto where he organized a new department and established teaching in economics on a sound historical footing. In 1892 he went to Harvard where the first chair in economic history in the English-speaking world was created for him. While there he was also active in the Quarterly Journal of Economics and in the editing of his series of Economic Classics. In I90I Ashley returned to England to join the staff of the newly organized University of Birmingham as Professor of Commerce-the first chair of its kind in Britain. Though opposed at the outset both by academics and businessmen the course of studies that Ashley administered soon won acceptance and was widely copied by other universities, which came later into this field. He retired in 1925 and died two years later at the age of 67 .

Ashley first made his mark as a scholar with his Early History of the English Woollen Industry (Baltimore, 1887) and his Introduction to English Economic History and Theory ( 2 vols., London, 1888-93), and from the publication of these works until his The Economic Organization of England (London, 1914) he maintained in books and articles a steady though diminishing stream of scholarly work. Increasingly after his return to England in 190r he was involved in university administration and also in public affairs. At the University of Birmingham he became Vice-Principal as well as Dean of the Faculty of Commerce. Outside the University he actively engaged in the Tariff Reform Movement as Joseph Chamberlain's chief academic adviser and was a member of a number of official economic committees and commissions. He was given an honorary $\mathrm{Ph} . \mathrm{D}$. by the University of Berlin in 1910 and was knighted in 1917.

Lujo Brentano (1844-1931), Ashley's correspondent in the letters here published, was as prominent a member of the German school of Schmoller and Sombart as Ashley was of the English school of Toynbee and Cunningham. He met English scholars and acquired a lively interest in English affairs during a visit in 1868 devoted to the study of English trade unionism. His reputation as a scholar was made with his Die Arbeitergilden der Gegenwart (Leipzig,

- These letters were lent to Mr. McCready by Professor Brentano's daughter, Miss Sophie Brentano of Prien, Chiemsce, West Germany. The originals have been returned, but Mr. McCready retains microfilm copies. 
I871-1872). He served as Professor of Political Economy at Breslau, Strassburg, Vienna, Leipzig, and Munich. ${ }^{1}$

H. W. McCREAdY, McMaster University

Dear Professor Brentano:

University of Toronto, Ontario, October 16, I890.

I have made up my mind to become a candidate for the chair of Political Economy at Oxford, which has just been rendered vacant by the untimely death of Thorold Rogers; and my purpose in writing to you is to ask you if you could see your way to give me a few words of "testimonial". I feel very keenly how presumptuous it must seem on the part of so young a man to put himself forward for so honourable a post; and I should not do so were there any senior man of pre-eminent claims in the field. But there is not; and in the present position of studies at Oxford, I think I may claim to be not altogether unsuited for the work. For the one chance of promoting the study of Economics at Oxford is to connect it with the Historical department, in which I obtained my own training, and had my first experience in teaching. Students in the "School" or department of "Literae Humaniories" are indeed expected to give some attention to Political Economy; but the number of other subjects they have to study is so great, and they (those other subjects) are so much more important in the examination, that they can devote but very little time to Economics. In the "School" of History on the other hand, Economic Theory and Economic History are both among the important subjects for examination; and I am convinced that a Professor who would seek to organise the work of his chair so as to bring it in touch with the Historical work of the students, would be able to secure a wide influence and create a band of fellow workers.

If you would have the goodness to give me a written judgement of my work hitherto, especially in Economic History,-if, without putting any strain on your conscience, it were at all a favourable one-I am sure it would be of weight in England. I ought perhaps to make some explanations as to my course hitherto. I took my degree in $\mathrm{I} 88 \mathrm{I}$ in Modern History, and in 1882 received one of the University Prizes for an Essay on the Arteveldes. ${ }^{2}$ It was during $188 \mathrm{I}-2$ that $\mathrm{I}$ began to study Political Economy seriously under Arnold Toynbee, whom I regard more than any other man as the source of whatever inspiration has come to me in the investigation and teaching

1 On Ashley see, Anne Ashley, William James Ashley, a Life (London, 1932); A. P. Usher, "William James Ashley: A Pioneer in Higher Education," Canadian lournal of Economics and Political Science, May 1938, pp. 151-63; "William James Ashley," Encyclopaedia of the Social Sciences.

2 James and Philip van Artevelde, Lothian Prize Essay (London, 1882). 
of the subject. ${ }^{8}$ I resided in Oxford as a private tutor until the beginning of 1885 , but during that period I took a considerable share in the preparation of Toynbee's lectures, and the volume issued in I884 was largely based on my notes (see Mrs. Toynbee's Prefatory Note, at the top of p. xxxi). For the second edition I also prepared the index which is now annexed to it.

In February 1885 I was elected to a Fellowship at Lincoln College, with tutorial work in History both at Lincoln and at Corpus Christi Colleges; and I at once began to give lectures to audiences consisting during some terms of as many as 80 or 100 students, both in Modern Economic Theory, and also, and more usually, on the development of Economic History and Theory. Moreover, in I886 I created and subsequently acted as Secretary to the Oxford Economic Society, composed of most of the senior resident members of the University interested in Economic questions. But in 1888 I felt that my best powers lay in the direction of Political Economy, and that it was a mistake for me to devote so much of my time to Political and Constitutional History as my tutorial position compelled me to do. Accordingly I resigned my Oxford position, and accepted the Professorship ${ }^{4}$ in order to be able to devote the whole of my time \& energy to the study \& teaching of Economics. During the last two years therefore I have had the work of creating a new department in this University; I have lectured in Economic Theory, Economic History and Finance to considerable audiences; \& I have made a beginning in the direction of Seminary work, as you will see by Mr. McEvoy's essay, ${ }^{b}$ of which I believe a copy was sent to you. Two other essays by my pupils are now almost ready for publication, one on the History of Currency and Banking in Canada, and the other on Municipal Works. ${ }^{6}$ My residence here has also given me opportunities to come in contact with business men, and to study the workings of modern financial operations.

You have, I think, seen most of my writings; my Early History of the English Woollen Industry published by the American Economic Association in 1887 was the first attempt to trace in any detail the history of England's greatest industry. Then in April, 1888 was published the first volume of my Economic History, ${ }^{7}$ which has been successful beyond my wildest expectation. It grew out of an attempt to print the outline of my lectures: the book grew under my hand, and I found myself obliged to undertake some little special investigation on many points. It by no means deserves all the

3 Arnold Toynbee (1852-83), a disciple of T. H. Green, was led to economic history by his philanthropy. He was a tutor at Balliol when his lectures on the Industrial Revolution were given in $188 \mathrm{I}-82$.

4 At the University of Toronto.

6 J. M. McEvoy, The Ontario Township, Toronto University Studies in Political Science, Series I, No. I, edited by J. W. Ashley (Toronto, 1889).

O Only A. H. Sinclair, Municipal Monopolies and their Management, Toronto University Studies in Political Science, Series I, No. 2, edited by J. W. Ashley (Toronto, 1891), was published.

7 An Introduction to English Economic History and Theory (London, 1888). 
good things that have been said of it; for you will at once see how largely I have built on the work of others, and that my task was one chiefly of systematization. However it has set me on the path which I intend to pursue for many years of the future-I hope with far more original investigation. For the last two years I have devoted all the time I could spare to the economic facts \& theories of the 14th-16th centuries; and I hope to bring out the second part some time next year. ${ }^{8}$

It is my knowledge of your keen interest in all that concerns England which prompts me to invite your aid, if you feel that you can give it. If indeed, you feel more sympathy with the claims of any other candidate, you will not scruple to tell me so. But if not, a few words of comment on my economic work, by one who like yourself, is regarded as an authority in England, would be of the utmost value. If you can send me anything of the kind, please send it to me at the above address.

Believe me

Sincerely yours,

W. J. Ashley.

University of Toronto, Canada, Feb. 9, 1892 .

My dear Professor Brentano:

May I ask you to be so good as to put me in the way of obtaining certain information, if it is at all accessible? I find that I am in a position to influence to some extent public opinion in Canada in the direction of accepting the principle of Trades Unions; $^{\boldsymbol{9}}$ and one of the most effective arguments, as I have soon seen, has been to present them as the necessary basis for the successful working of Boards of Conciliation. I shall soon be taking an opportunity to explain at length the working of such Boards in other countries. I can, of course, point to the English experience; but the American and Canadian public is sometimes a little jealous of England, and more likely to be moved by a reference to the experience of other countries. Are there any fairly successful experiments of the nature of Boards of Conciliation at present in Germany? I find in Schönberg ${ }^{10}$ an account by yourself of the working of Einigungskammern; but no reference to German experience. If you chance to know of any German, French or Italian facts that would be of service to me, and could help me to obtain them, I should be much obliged, and you would be doing a service to a cause you have at heart. You might chance to have reports or pamphlets by you that you did not need to retain, or that you could lend to me for two or three weeks. Or you

8 The second volume appeared in 1893 .

O Unions, though long established in Canada, still found little favor with the general public. See Part II of H. A. Logan, Trade Unions in Canada; Their Development and Functioning (London, 1948).

10 Gustav von Schönberg, Handbuch der politischen Oekonomie... Herausgegeben von Gustav von Schönberg, 2 vols. (Tubingen, 1882). 
might be able to indicate to me the names of recent books in which I could find useful information.

I ventured to send you lately a copy of my article in the Economic Journal with a reference to Marshall's criticism of your argument as to the classical economists \& the iron law of wages. ${ }^{11}$ And in the Political Science Quarterly for September I8gr I have taken up an attitude towards Dr. Gross's attack on you, which though it may surrender more than you are inclined to give up, is yet a defence of your main position. ${ }^{12}$ We English economists owe so much to you, that you deserve at least bare justice!

Very truly yours,

W. J. Ashley.

\section{The Quarterly Journal of Economics}

Dear Professor Brentano:

6 Acacia St., Cambridge, Mass., Dec. II, 1893 .

I am asked by Professor Dunbar, the senior professor here of Political Economy, ${ }^{18}$ and by the rest of my felloweditors of the Quarterly Journal of Economics, to approach you with a view of discovering whether there is any likelihood that we may obtain an article from your pen. It was felt by all of us that we should be fortunate if we could induce you to write an article surveying and criticizing recent literature bearing on English Economic History; and it occurred to me after reading your article on the Hineingewerb in Schlesien in the Zeitschr. f. Soc. U. Wirtschaftsgeschichte that you might like to combine with this some consideration of the present position of the study of economic history.

The books which Professor Dunbar had especially in mind when he made the suggestion first were the two volumes of Cunningham's English Industry and Commerce (1890, 1892), and the second part of my own Economic History (1893). But with these you might like to associate Hewins' little book on English Trade and Finance (1892), and even to go back and say something on Dr. Gross' Gild Merchant (1890). You might think fit to mention Schulze-Gaevernitz, ${ }^{14}$ or Mrs. Webb's Cooperative Movement. But the precise scope would, of course, be left altogether to your judgement; and I need hardly add that a satisfactory honorarium would be paid. We should like to have the M.S. in time for publication on July $\mathbf{~}$.

11 "The Rehabilitation of Ricardo," September 1891, pp. 474-89.

12 "General Booth's Panacea," pp. 537-50.

18 Charles Franklin Dunbar was the first professor of Political Economy at Harvard (18711900) and the founder and first editor of the Quarterly lournal of Economics (1876-94).

14 Gerhard von Schulze-Gaevernitz, Zum socialen Frieden, Eine Darstellung der social. politischen Erziehung des englischen Volkes im neunzehnten lahrhundert, 2 vols. (Leipzig, $1890)$. 
Although I had some hesitation in writing to you-since, as I have remarked above, my own recent book was itself one of those which Professor Dunbar wished you to consider, I have ventured to do so feeling that I might perhaps be able to put the matter before you in a way which would commend it to your sympathy.

You are probably aware that the Harvard Quarterly Journal has hitherto largely devoted itself to theoretic discussions. It was, for instance, in its pages, that the Austrian economists were first introduced to the American public. The teaching here, moreover-which was coloured by the influence of Professor Dunbar-interested itself chiefly in the old doctrines and in finance. But Professor Dunbar has himself seen the desirability of widening the scope and adding to the varieties of the teaching here; and last year I was invited to take the newly-created chair of Economic History (while Assistant Professor Cummings devotes himself to Social Politics). With the beginning of 1894 the Harvard Quarterly Journal, hitherto managed by Professor Dunbar, will be managed jointly by Professors Dunbar, Taussig, Cummings and myself. You will understand therefore the keen pleasure it would be to me, if the ideas which you have so long and so worthily championed as to economic method could find fitting expression in its pages; and it seems to me that in the shape of a review of recent literature you could tell the American public something of the place that Economic History ought to occupy and the way in which it should be studied.

Moreover, there is this additional reason to move you. The Harvard Quarterly Journal is the oldest purely economic journal in the U. S.; and the example of Harvard is very influential upon the other American colleges. I do not know any medium through which you would be more likely to affect the future thought of young American scholars than the Harvard Journal.

I am aware how bold I am in urging upon you this request. From many sources I learn of the great work you are conducting at Munich, and I know your time must be fully occupied. But I have thought that a proposal such as this, having a certain missionary character about it, might enlist your sympathies; and if you could see your way to it, it would be a great pleasure to one who has learned very much from you.

Believe me

Very sincerely yours

W. J. Ashley

Oct. 30,1896

Harvard University.

Dear Professor Brentano,

I have just received to my great gratification the second volume of the 
translation of my History, ${ }^{15}$ and I have written to Mr. Oppenheim ${ }^{16}$ to convey my very hearty thanks. But I feel that I am also under a personal obligation to yourself, for your editorial supervision (and I trust you did not find the labour great), and still more for your readiness in the first instance to find a place for it in your Sammlung. You, to whom success came so early, have probably forgotten what a keen pleasure it is to a scholar when his work finds such a recognition in other lands as to be deemed worthy of translation. No one understands the weaknesses of the book better than I do. It was begun with a very inadequate preparation: it grew upon my hands until the earlier and later parts are out of proportion; the later volume supplements and corrects the first in a very unsymmetrical fashion. Still it may be of some use for some German scholars as it has been to English as an introduction to some of the literature of the subject, and as putting together material previously scattered in very heterogeneous quarters.

I sent you recently, I believe, a little review of mine of recent German and French work on early town history. ${ }^{17}$ That must be my "Swan song" as a mediaevalist-for some time to come. For various reasons I am now turning to modern themes; and this year I am lecturing on Economic Thought down to Mill and on Economic History from 1500 to 1800 .

I have got the two things edited by Lotz and Gothein in your Sammlung and expect to make a good deal of use of them; and I shall soon receive the Bernoulli which I am glad to see you have had translated. In my own series of Economic Classics the next volume will be a translation of Turgot, from the text as reconstituted by Schelle. ${ }^{18}$ Need I say with what joy we shall all receive the first volume of your Lehrbuch, when you see your way to publish it. ${ }^{19}$

\section{With renewed thanks \\ Believe me \\ Sincerely yours \\ W. J. Ashley.}

P.S. You may be interested in the papers prepared for class use which I am sending under another cover. They illustrate, among other things, the difference of the Harvard from the German method. We compel all our students to do some work: it is good for them, but not so good for us.

W. J. A.

15 The German translation of Ashley's Economic History appeared in 1896 as one of a series of texts edited by L. Brentano and E. Leser, Sammlung älterer und neurer staatswissenschaftlicher Schriften des In- und Auslandes (Leipzig, 1893, etc.).

16 The translator.

17 "The Beginnings of Town Life in the Middle Ages," Quarterly Journal of Economics, July 1896 , pp. $359-406$.

18 A. R. J. Turgot (1727-8I), Reflections on the Formation and the Distribution of Riches (1770) (New York, 1898).

19 Agrarpolitik. Ein lehrbuch von dr. Lujo Brentano, I teil: theoretische einleitung in die agrarpolitik (Sturtgart, 1897) (no more published). 
Mid Atlantic, Sept. 19, 1901

Dear Professor Brentano:

Before I enter upon my English duties, and become immersed in the details of administration, I want to thank you for the words of commendation which were of such material assistance to me in the Birmingham candidature. I have not seen what you wrote in answer to Dr. Cunningham's request, and probably I never shall. But I knew that your opinion carried weight.

Now that England has become my home, I trust it will be possible for me to make the personal acquaintance of an economist from whom I have learned so much, but of whom hitherto I have had but a passing glimpse -in Leeds eleven years ago. My American experience has convinced me that England and Germany are natural allies; and in my new position I hope to be able in some small measure to make my fellow-countrymen understand better the situation and aspirations of our Teutonic neighbors. You have been good enough to send me copies of your publications from time to time, and you will surely not discontinue this kindly practice. But it would be better still if I could have the advantage of consulting you in person; and accordingly I venture to add that if circumstances should ever bring you to Birmingham, there is a house-at 3 Yateley Dr., Edgbaston,-which would be proud to entertain you.

$$
\begin{aligned}
& \text { Believe me } \\
& \text { Sincerely yours } \\
& \text { W. J. Ashley. }
\end{aligned}
$$

Dear Professor Brentano,

[He thanks Brentano for copies of the Frankfurter Zeitung containing articles by Brentano.]

It occurred to me that your reference to my "old defence" of Trades Unions is possibly due to an impression that I have in some way changed my attitude in regard to them. This is not the case; as you will see if you will be good enough to look at my book, issued in 1903, The Adjustment of Wages (Longman). ${ }^{20}$ Some account of it will be found in Soziale Praxis for August 20, 1903 .

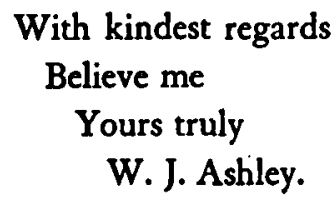
America (London, 1903). 
P.S. In my more recent writings on Imperial Preference etc. I have not needed to deal with $T$. Unionism at any length. But wherever $I$ have touched upon it, my sympathies have been unmistakeable. See Tariff Problems, pp. 189-192, Progress of German Working Classes, p. 136-p. 148. ${ }^{21}$

$$
\text { W. J. A. }
$$

Dear Professor Brentano,

February 2I, 1913

Let me thank you very warmly for sending me your Syndikalismus etc. ${ }^{22}$ I have spent four interesting hours this afternoon in reading it through from cover to cover. I need hardly say that I altogether agree with the position you take up, and have taken up for many years. I admire the courage and public spirit with which you proclaim opinions so wise and salutary, and I congratulate Germany on its possessing such a man.

While I altogether agree in substance with what you say about Syndicalism -and I think your explanation, in particular, of its special prevalence in France, is quite true, you won't mind my saying that I think you possibly underestimate its vogue in England. There are very few who call themselves Syndicalists in England; but Mann ${ }^{23}$ did succeed in creating something like an organization; and the London labour paper-the Daily Herald (run by Lansbury in opposition to the Daily Citizen, the Manchester labour paper) -seemed, in a number which I recently picked up, to combine a sort of Syndicalism with Women's Suffrage. But what is, I think, much more important, is that the Welsh miners last year were greatly influenced (against their trade union officials) by younger men who (without calling themselves Syndicalists) shared some of the leading Syndicalist ideas: the dislike to Parliamentarism, to Conciliation, to Representation,-the belief in Direct Action, the Irritation Strike (a form of Sabotage), and the ultimate control of production by Industrial Unions. ${ }^{24}$

There is a passage on $\mathrm{p}$. 100 which may be misunderstood by your readers. I haven't the text of Ramsay Macdonald's speech; but I suspect if you look at it, you will find that he only asked for the legal enforcement on the employers (Rechtsverbindlichkeit) of a minimum wage. Rechtsverbindlichkeit of Taufvertrage in general, upon employed as well as employers, in the sense of N. Zealand or N. S. Wales, has I think been voted down again and

21 The Tariff Problem (London, 1903); The Progress of the German Working Classes in the Last Quarter of a Century (London, 1904).

22 Uber syndikalismus und lohnminimum etc. (Munich, 1913).

28 Tom Mann, leader of the great dock strike of 1889 , first Secretary of the Independent Labour Party, was a professional agitator of 'revolutionary bent, first on syndicalist and then on communist lines. On Mann's syndicalist movement see $\mathrm{S}$. and B. Webb, The History of Trade Unionism (London, 1926), pp. 657-59.

24 On this matter see, The Miners' Next Step (London, 1912). 
again of recent years by large majorities in the $T$. Union Congress, as interfering with the "right to strike."

\author{
Believe me \\ Very truly yours \\ W. J. Ashley.
}

March 25, 1913

Dear Professor Brentano,

Thanks for your interesting letter of the 22nd.

I am sorry you find it necessary to draw so gloomy a picture of German conditions. In spite of what you say, I can't help thinking that it is a little too gloomy. My impression is that the loss of the old idealism (so far indeed as it is lost) has been due to the growth of Industrialism and Capitalism, Machinery, Transport, International Speculation, etc., etc. Of this the Protection of manufacturers is, I should think, an outcome-not a cause. And I imagine the same growth of luxury and loss of idealism is to be seen in Free Trade countries, like Holland. Moreover, there may be something to be said on the other side. When I looked into the history of German working class conditions since 1879 a few years ago, it seemed to me that there was visible a distinct improvement in the material condition of the people. I understand that Edward Bernstein told someone that the main proposition of my book could not be denied. It might doubtless be argued that, but for Protection the improvement would have been greater. I mention the matter only to suggest that possibly the shadows in your picture might be a little relieved.

As to England, I don't see how it can be said that the period of the most complete dominance of Free Trade doctrine-say 1860-1880-was a period of idealism. I need only refer you to the contemporary books of Matthew Arnold-Culture and Anarchy, Friendship's Garland, etc. And no one can fairly judge of the present "protectionist" movement in England who regards it simply as the outcome of selfishness on the part of manufacturers. It is largely, especially on its Preferential side, the outcome of a new Idealism, the Idealism of a noble conception of the British Empire and the services it can render to Humanity. And among the young men of 25-45 who are keen Imperialists there are many who are equally keen Social Reformers. To quote your own phrase, "you may not like to hear that"; but these are among the facts, at any rate, that have to be taken into consideration. I was brought up a strong Liberal and many of my most intimate friends are strong Liberals: but since I began to care for Social Reform under Toynbee's influence (1882) I have been indifferent towards the claims of the Liberal party just because the party has never, in any deep sense, been fundamentally the party of social reform.

Yours very sincerely,

W. J. Ashley. 